\title{
Day-care, early common infections and childhood acute leukaemia: a multicentre French case-control study
}

\section{F Perrillat', J Clavel*,', MF Auclerc², A Baruchel ${ }^{3}$, G Leverger $^{4}$, B Nelken $^{5}$, N Philippe $^{6}$, G Schaison $^{3}$, D Sommelet ${ }^{7}$, E Vilmer $^{8}$ and D Hémon'}

\begin{abstract}
'Institut National de la Santé et de la Recherche Médicale, Inserm UI70, 16 avenue Paul Vaillant Couturier, 94807 Villejuif, France; ${ }^{2}$ Institut National de la Santé et de la Recherche Médicale, Institute of Hematology, Saint-Louis Hospital, 75010 Paris, France; ${ }^{3}$ Department of Paediatric Haematology, SaintLouis Hospital, 75010 Paris, France; ${ }^{4}$ Department of Paediatric Haematology, Armand Trousseau Hospital, 75012 Paris, France; ${ }^{5}$ Department of Paediatric Haematology-Oncology, Jeanne de Flandre Hospital, 59000 Lille, France; ${ }^{6}$ Department of Paediatric Oncology, Debrousse Hospital, 69009 Lyon, France; ${ }^{7}$ Department of Paediatric Oncology, Brabois Hospital, 54000 Nancy, France; ${ }^{8}$ Department of Paediatric Haematology-Immunology, Robert Debré Hospital, 75019 Paris, France
\end{abstract}

We conducted a case-control study to investigate the role of early infections in the aetiology of childhood acute leukaemias. The study included 280 incident cases (240 acute lymphoblastic leukaemia and 40 acute non-lymphoblastic leukaemia) and 288 hospital controls, frequency matched by age, gender, hospital, catchment area of the hospital and ethnic origin. Data were obtained from standardised face-to-face interviews of the mothers. The interviews included questions on early common infections, day-care attendance, breast-feeding, birth order and infantile diseases. Odds ratios were estimated using an unconditional regression model including the stratification variables, parental socio-economic status and perinatal characteristics. Birth order was not associated with childhood leukaemia (acute lymphoblastic or acute non-lymphoblastic). A statistically-significant inverse association was observed between childhood leukaemia and day-care attendance (odds ratio $=0.6,95 \%$ Confidence Interval $=(0.4-1.0)$ ), repeated early common infections ( $\geqslant 4$ per year before age two, odds ratio $=0.6(0.4-1.0)$ ), surgical procedures for ear - nose -throat infections before age two (odds ratio $=0.5(0.2-1.0)$ ) and prolonged breast-feeding ( $\geqslant 6$ months, odds ratio $=0.5(0.2-1.0)$ ). In the multivariate model including day-care attendance, early common infections and breast-feeding, results concerning breast-feeding remained unchanged. A statistically significant interaction between day-care attendance and repeated early common infections was observed. When the interaction was taken into account, the simple effects of day-care and early common infections disappeared (odds ratio $=1.1(0.5-2.3)$ and odds ratio $=0.8(0.5-1.3)$, respectively) while the joint effect of day-care attendance and early common infections was negatively associated with childhood leukaemia (odds ratio $=0.3(0.1-0.8)$ ). All the above associations were observed both for acute lymphoblastic leukaemia and acute non-lymphoblastic leukaemia. Our results support Greaves' hypothesis, even though they are not specific of common leukaemia.

British Journal of Cancer (2002) 86, 1064 - 1069. DOl: 10.1038/sj/bjc/660009 I www.bjcancer.com

(c) 2002 Cancer Research UK

Keywords: childhood leukaemia; risk factors; day-care; early infections; breast-feeding

Little is known about the aetiology of childhood acute leukaemia $(\mathrm{AL})$, which is the most frequent childhood cancer world-wide (Doll, 1989; Ross et al, 1994). An infectious aetiology has been suggested for many years, particularly since specific viruses have been shown to be involved in leukaemia in animals (Essex, 1982). However, no specific virus has been found to explain childhood leukaemia. Kinlen postulated that childhood leukaemia occurs as a rare response to a specific infection(s) and increased by marked rural-urban population mixing (Kinlen, 1988, 1995; Kinlen et al, 1990; Kinlen and Petridou, 1995). Greaves hypothesised that common B-cell leukaemia, which is responsible for the incidence peak observed between ages 2 and 5 years, may result from a two-step process, with a first step occurring in utero (Greaves, 1988). Greaves suggested that the risk of childhood

*Correspondence: Dr J Clavel, E-mail: clavel@vjfinserm.fr Received 30 July 200 I; revised 29 November 200 I; accepted 29 November 2001 common B-cell leukaemia is increased by an immune proliferative stress. By contributing to the normal maturation of the immune system, early common infections or factors favouring infections in childhood would thus protect the child against leukaemia, while a situation of relative isolation would make the child more vulnerable (Greaves and Alexander, 1993; Greaves, 1997).

This article reports the results of a French case-control study designed to investigate the role of early common infections and factors influencing early common infections (day-care attendance, breast-feeding, and birth order) in childhood AL.

\section{SUBJECTS AND METHODS}

\section{Subjects}

A hospital-based case-control study was conducted in the hospitals of Lille, Lyon, Nancy and Paris (France). To be eligible, cases were required to be aged 15 years or less, reside in the hospital catchment area, and have a recent diagnosis of $\mathrm{AL}$, i.e. diagnosis 
between January 1, 1995 and December 31, 1999. The hospitalbased design of the study was chosen since case and control blood samples were required. Special care was therefore paid to selecting an appropriate control group. The controls were children hospitalised in the same hospital as the cases, mainly in orthopaedic and emergency departments, and residing in the catchment area of the hospital. Many different diagnostic categories were included in order to avoid selection biases in the event that a particular disease was related to the exposures of interest (Breslow and Day, 1980; Rothman and Greenland, 1998). However, children hospitalised for cancer or a major congenital malformation were not eligible for the study, since those diseases may share risk factors with leukaemia. Recruitment was frequency matched by age, gender, hospital, hospital catchment area and ethnic origin (Caucasian, North African, others). Of the mothers of the 282 cases and 291 controls who were eligible for interview during the interviewers' working hours, two cases and two control mothers refused to participate. We excluded one control child who was adopted. Thus, a total of 280 incident cases of $\mathrm{AL}$ confirmed by cytology, consisting of 240 cases of acute lymphoblastic leukaemia (ALL) and 40 cases of acute nonlymphoblastic leukaemia (ANLL), and 288 controls were included in the study.

\section{Data collection}

The mothers of the cases and controls were interviewed when the index child was in complete remission or in good condition (on average, 2 months post-diagnosis), using a standard questionnaire administered by trained medical interviewers. Interviews were performed in the hospitals under strictly similar conditions for the cases and controls. Neither the parents nor the interviewers were informed of the hypothesis underlying the study. Data relating to early infections and factors promoting infections included: birth order of the index child; interval to birth of the immediately elder sibling (intervals less than 2 and less than 5 years were examined); duration of breast-feeding; history of day-care attendance; history of early common infections; history of surgical procedures for early ear-nose-throat (ENT) infections; and infantile diseases. 'Repeated early common infections' was defined as four or more common infections per year before age 2. Surgical procedures for early ENT infections were defined as: adenoidectomy, tonsillectomy, tympanostomy tube insertion and tympanocentesis before age 2 years. The procedures were used as a surrogate for early, repeated, ENT infections.

\section{Statistical analysis}

All analyses were performed using the SAS computer software. Odds ratios (OR) were estimated using an unconditional logistic regression model including stratification variables, i.e. gender, age, ethnic origin and hospital. The socio-demographic characteristics (maternal educational level and parental socio-professional category) and perinatal characteristics (birth weight, length of pregnancy and number of pregnancies) were taken into account as potential confounders. The analyses of day-care attendance, early infections, breast-feeding and infantile diseases were conducted on the children aged over 2 years in order to be certain that early infections before age 2 would have already taken place in both the cases and controls. In the same way, multivariate analyses were conducted on the children aged over 2 years. Testing for interactions was systematically conducted. Two different final models were generated using two different variables as markers of early infections. In one model, 'repeated infections before age 2' and, in the other, 'surgical procedures for ENT infections before age 2' were used. In both, day-care and breastfeeding were included.

\section{RESULTS}

Most of the controls (88\%) were recruited in an orthopaedic or emergency department (Table 1). Sixty per cent of the cases were $2-6$ years old, $v s 55 \%$ of the controls. The recruitment of controls in the age bracket 2-6 years (i.e. the childhood leukaemia incidence peak) was very difficult. Cases and controls were very similar with respect to gender, hospital, hospital catchment area, ethnic origin, maternal occupation at the time of interview, maternal educational level, parental socio-professional category and urban/rural residence status (Table 1). The cases and controls did not differ with respect to birth weight, length of pregnancy or number of pregnancies. However, reduced length of pregnancy

Table I Sample description for the cases and controls

Cases (\%) Controls (\%) P

\begin{tabular}{|c|c|c|c|}
\hline \multicolumn{4}{|l|}{ Diagnosis catergories } \\
\hline Acute lymphoblastic leukaemia & $240(86)$ & - & \\
\hline Pro B-cell & $17(7)$ & & \\
\hline Common B-cell/Pre B-cell & $|8|(75)$ & & \\
\hline Mature B-cell & $5(2)$ & & \\
\hline T-cell & $30(13)$ & & \\
\hline Failure/Unclassified & $7(3)$ & & \\
\hline Acute non lymphoblastic leukaemia & $40(14)$ & - & \\
\hline Traumatism (fractures, pounds, burns'...) & - & $154(54)$ & \\
\hline Osteo-articular diseases (arthritis, osteomyelitis'...) & - & $100(35)$ & \\
\hline Digestive, urinary and genital symptoms & - & $17(6)$ & \\
\hline Minor congenital disorders & - & $6(2)$ & \\
\hline Others & - & II (4) & \\
\hline \multicolumn{4}{|l|}{ Gender $^{\mathrm{a}}$} \\
\hline Male & $166(59)$ & $168(58)$ & ns \\
\hline \multicolumn{4}{|l|}{ Age (years) ${ }^{\mathrm{a}}$} \\
\hline$<2$ & $33(12)$ & $5 \mid(18)$ & \\
\hline $2-3$ & $85(30)$ & $53(18)$ & \\
\hline $4-6$ & $83(30)$ & 79 (27) & *⿻丷木 \\
\hline $7-10$ & $41(15)$ & $63(22)$ & \\
\hline$\geqslant 11$ & $38(14)$ & $42(15)$ & \\
\hline \multicolumn{3}{|l|}{ Hospital ${ }^{a}$} & ns \\
\hline Lille & $39(14)$ & $26(9)$ & \\
\hline Lyon & $36(13)$ & $35(12)$ & \\
\hline Nancy & $23(8)$ & $22(8)$ & \\
\hline Paris & $182(65)$ & $205(7 \mid)$ & \\
\hline \multicolumn{3}{|l|}{ Catchment area of hospital $^{\text {a }}$} & ns \\
\hline Inside & $273(97)$ & $284(99)$ & \\
\hline Outside & 7 (3) & I (I) & \\
\hline \multicolumn{3}{|l|}{ Ethnic origin ${ }^{\mathrm{a}}$} & ns \\
\hline Caucasian & $244(87)$ & $236(82)$ & \\
\hline North African & $15(5)$ & $25(9)$ & \\
\hline Caribbean & $4(1)$ & $5(2)$ & \\
\hline African & $2(1)$ & $6(2)$ & \\
\hline Asian, Middle Eastern & $2(1)$ & $6(2)$ & \\
\hline Mixed, others & $13(5)$ & $10(3)$ & \\
\hline \multicolumn{3}{|l|}{ Maternal education } & ns \\
\hline$\leqslant$ high school & $190(68)$ & $176(62)$ & \\
\hline$>$ high school & $90(32)$ & $108(38)$ & \\
\hline \multicolumn{3}{|l|}{ Maternal activity at time of interview } & ns \\
\hline Yes vs no & $173(62)$ & 191 (67) & \\
\hline \multicolumn{3}{|l|}{ Socio-professional catergories } & ns \\
\hline \multicolumn{4}{|l|}{ Professional, technical workers } \\
\hline Clerical, sales and services workers & $55(20)$ & $\begin{array}{r}160(56) \\
49(17)\end{array}$ & \\
\hline Factory and agricultural workers & $78(28)$ & $76(27)$ & \\
\hline \multicolumn{3}{|l|}{ Place of residence } & ns \\
\hline Urban (>5000 inhabitants) & $221(79)$ & $234(83)$ & \\
\hline Rural $\quad(\leqslant 5000$ inhabitants) & $58(21)$ & $49(17)$ & \\
\hline
\end{tabular}

aMatching variables; $\mathrm{ns}=P>0.05 ; * * P<0.01$ 
and low birth weight were both, and independently, negatively related to prolonged breastfeeding ( $>6$ months). Conversely, parity was positively related to prolonged breastfeeding.

No association between birth order and childhood leukaemia (ALL or ANLL) was observed (Table 2). The OR associated with a time interval to immediately elder sibling birth of less than 2 years was less than unity, but the association was far from statistical significance $(\mathrm{OR}=0.6,95 \%$ Confidence Interval $=(0.2-1.7))$. The OR was close to unity when the interval to birth of the immediately elder sibling was less than 5 years $(\mathrm{OR}=0.8(0.6-1.3))$.

The results for early infections, day-care attendance and breastfeeding are shown in Table 3. A statistically-significant inverse association between day-care attendance and childhood $\mathrm{AL}(\mathrm{OR}=0.6$ $(0.4-1.0))$ was observed. The association was more pronounced for children having started day-care at age 6 months or less $(\mathrm{OR}=0.5(0.3-1.0))$ than for children having started day-care at age 13 months or more $(\mathrm{OR}=0.8(0.3-1.8))$. Nevertheless, the trend for age of starting day-care was not statistically significant. Repeated common infections before age 2 and surgical procedures for ENT infections before age 2 were statistically and negatively associated with childhood leukaemia $(\mathrm{OR}=0.6(0.4-1.0)$ and $\mathrm{OR}=0.4(0.2-1.0)$, respectively). Lastly, breast-feeding for at least 6 months was negatively associated with childhood leukaemia with an OR of $0.5(0.3-1.1)$ and an OR of $0.5(0.2-1.0)$ after adjustment for perinatal characteristics (birth weight, length of pregnancy, number of pregnancies).

The results of the joint analyses of early infection and breastfeeding are shown in Table 4. The model including day-care, repeated infections before age 2 and breast-feeding, showed a significant interaction between day-care attendance and common infections before age $2(\mathrm{OR}=0.3(0.1-0.8))$. The model including day-care, surgical procedures for ENT infections before age 2 and breast-feeding, did not show any interaction. For both models, the estimations were not altered by the mutual adjustments. Similar results were observed for ALL (common or not) and ANLL.

The variables of interest were identically distributed over the different diagnostic categories in the control group. Moreover, the estimations of the above associations remained the same when the control group was restricted to the main diagnostic categories, i.e. injury or osteoarticular diseases. The $\mathrm{OR}$ were: $\mathrm{OR}=0.3(0.1-$ 0.8 ) and $\mathrm{OR}=0.3(0.1-0.7)$, respectively, for the joint effect of day-care and repeated early common infections; OR $=0.4(0.2-$ $1.1)$ and $\mathrm{OR}=0.2(0.1-0.8)$ for ENT infections before age 2; and $\mathrm{OR}=0.5(0.2-1.3)$ and $\mathrm{OR}=0.4(0.1-1.2)$ for breast-feeding.

No association was found between measles, rubella or chickenpox and childhood leukaemia (Table 5). Elevated OR were observed for the association between childhood leukaemia and glandular fever and viral hepatitis, but based on very small numbers. A significant elevated $\mathrm{OR}$ was associated with mumps $(\mathrm{OR}=3.2(1.1-9.0))$.

\section{DISCUSSION}

Greaves suggested that early common infections in infancy and factors influencing early infections, such as birth order, older siblings, breast-feeding, and day-care, could have a protective effect against childhood AL (Greaves, 1988). A hospital-based casecontrol study was conducted in France to investigate the role of early infections in childhood AL. The hospital-based design of the study was chosen since case and control blood samples were required. Special care was therefore paid to selecting an appropriate control group. The reasons for which some case or control Frenchspeaking mothers were not eligible for interview consisted in the non-availability or vacation of the interviewer, except for the

Table 3 Association between childhood acute leukaemia and day care, early infections and breast-feeding in children older than 2 years

\begin{tabular}{|c|c|c|c|c|}
\hline & $\begin{array}{c}\text { Cases (\%) } \\
n=247\end{array}$ & $\begin{array}{c}\text { Controls (\%) } \\
n=237\end{array}$ & $O_{R^{a}}$ & $95 \% \mathrm{Cl}^{\mathrm{b}}$ \\
\hline $\begin{array}{l}\text { Day care } \\
\text { No } \\
\text { Yes }\end{array}$ & $\begin{array}{r}202(82) \\
44(18)\end{array}$ & $\begin{array}{r}173(73) \\
64(27)\end{array}$ & $\begin{array}{l}1.0 \\
0.6\end{array}$ & $\begin{array}{l}\text { Reference } \\
(0.4-1.0)\end{array}$ \\
\hline $\begin{array}{l}\text { Age at start of day ca } \\
\text { No day care } \\
>12 \text { months } \\
7-12 \text { months } \\
\leqslant 6 \text { months }\end{array}$ & $\begin{aligned} & 202(82) \\
& 11(5) \\
& 8(3) \\
& 24(10)\end{aligned}$ & $\begin{array}{l}173(73) \\
14(6) \\
12(5) \\
38(16)\end{array}$ & $\begin{array}{l}1.0 \\
0.8 \\
0.6 \\
0.5\end{array}$ & $\begin{array}{l}\text { Reference } \\
(0.3-1.8) \\
(0.2-1.7) \\
(0.3-1.0)\end{array}$ \\
\hline $\begin{array}{l}\text { Repeated infections be } \\
\text { No } \\
\text { Yes }\end{array}$ & $\begin{array}{l}\text { age } 2 \text { years } \\
116(50) \\
13(5)\end{array}$ & $\begin{array}{l}\text { 4/year) } \\
\quad 98(43) \\
21(57)\end{array}$ & $\begin{array}{l}1.0 \\
0.6\end{array}$ & $\begin{array}{l}\text { Reference } \\
(0.4-1.0)\end{array}$ \\
\hline $\begin{array}{l}\text { Surgical operation for } \\
\text { No } \\
\text { Yes }\end{array}$ & $\begin{array}{l}\text { ear-nose-thro } \\
234(95) \\
13(5)\end{array}$ & $\begin{array}{c}\text { nfections before c } \\
216(91) \\
21(9)\end{array}$ & $\begin{array}{c}2 \text { years } \\
1.0 \\
0.4\end{array}$ & $\begin{array}{l}\text { Reference } \\
(0.2-1.0)\end{array}$ \\
\hline $\begin{array}{l}\text { Breast-feeding }{ }^{c} \\
\quad \text { No breast-feeding } \\
\quad<6 \text { months } \\
\geqslant 6 \text { months }\end{array}$ & $\begin{array}{l}116(47) \\
114(46) \\
16(7)\end{array}$ & $\begin{array}{r}101(43) \\
105(45) \\
29(12)\end{array}$ & $\begin{array}{l}1.0 \\
1.1 \\
0.5\end{array}$ & $\begin{array}{l}\text { Reference } \\
(0.7-1.7) \\
(0.2-1.0)\end{array}$ \\
\hline
\end{tabular}

${ }^{\mathrm{a} O d d s}$ ratio (OR) were derived from an unconditional logistic model, adjusted for age, gender, hospital, ethnic origin, maternal educational level and parental socioprofessional category. ${ }^{b} 95 \% \mathrm{Cl}$ : $95 \%$ Confidence interval. ${ }^{\circ}$ Odds ratio (OR) were also adjusted for birth weight, length of pregnancy and number of previous pregnancies.

Table 2 Association between childhood acute leukaemia and birth order and siblings

\begin{tabular}{|c|c|c|c|c|c|c|c|c|c|c|c|c|}
\hline & \multicolumn{4}{|c|}{ All Acute Leukaemia } & \multicolumn{4}{|c|}{$\mathrm{ALL}^{\mathrm{a}}$} & \multicolumn{4}{|c|}{ ANLL ${ }^{b}$} \\
\hline & $\mathrm{Ca}^{\mathrm{c}}$ & $\mathrm{Co}^{\mathrm{d}}$ & $\mathbf{O R}^{\mathrm{e}}$ & $95 \% \mathrm{Cl}^{f}$ & $\mathbf{C a}$ & Co & OR & $95 \% \mathrm{Cl}$ & $\mathrm{Ca}$ & Co & OR & $95 \% \mathrm{Cl}$ \\
\hline \multicolumn{13}{|l|}{ Birth order } \\
\hline I & 63 & 75 & 1.0 & Reference & 55 & 75 & 1.0 & Reference & 8 & 75 & 1.0 & Reference \\
\hline 2 & 128 & 119 & 1.2 & $(0.8-1.9)$ & 113 & 119 & 1.2 & $(0.8-1.9)$ & 15 & 119 & 1.3 & $(0.5-3.6)$ \\
\hline 3 & 54 & 70 & 0.9 & $(0.5-1.5)$ & 46 & 70 & 0.9 & $(0.5-1.5)$ & 8 & 70 & 1.0 & $(0.3-3.0)$ \\
\hline $4+$ & 34 & 23 & 1.5 & $(0.8-3.0)$ & 28 & 23 & 1.4 & $(0.7-2.8)$ & 6 & 23 & 3.3 & $(0.9-12.4)$ \\
\hline $\begin{array}{l}\text { Interval to birth of next } \\
\text { older sibling less than } 2 \\
\text { years (yes vs no) }\end{array}$ & 6 & 9 & 0.6 & $(0.2-1.7)$ & 4 & 9 & 0.4 & $(0.1-1.6)$ & 2 & 9 & 1.0 & $(0.2-5.7)$ \\
\hline $\begin{array}{l}\text { Interval to birth of next } \\
\text { older sibling less than } 5 \\
\text { years (yes vs no) }\end{array}$ & 56 & 62 & 0.8 & $(0.6-1.3)$ & 50 & 62 & 0.9 & $(0.6-1.4)$ & 6 & 62 & 0.7 & $(0.3-1.8)$ \\
\hline
\end{tabular}

${ }^{a} \mathrm{ALL}$ : acute lymphoblastic leukaemia $(n=240) .{ }^{\mathrm{b}} \mathrm{ANLL}$ : acute non lymphoblastic leukaemia $(n=40) .{ }^{\mathrm{c}} \mathrm{Ca}$ : cases. ${ }^{\mathrm{d}} \mathrm{Co}$ : controls $(n=288) .{ }^{\mathrm{e}}$ Odds ratio (OR) were derived from an unconditional logistic model, adjusted for age, gender, hospital, ethnic origin, maternal educational level and parental socio-professional category. ${ }^{\text {f } 95 \% ~ C l: ~} 95 \%$ confidence interval. 
Table 4 Association between childhood acute leukaemia and multivariate analyses, in children older than 2 years

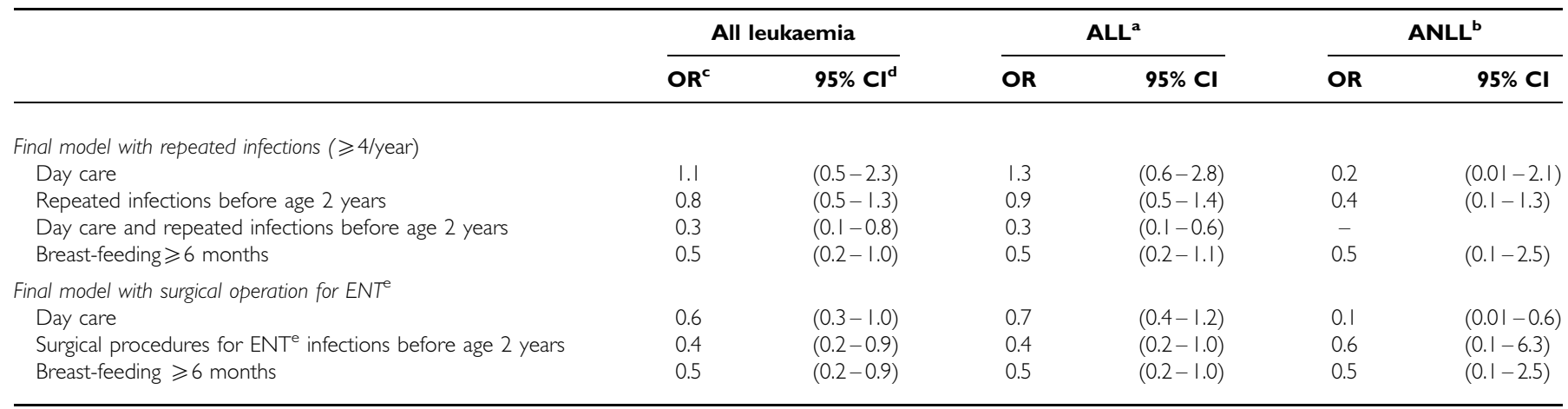

${ }^{a} A L L:$ acute lymphoblastic leukaemia $(n=240) .{ }^{b}$ ANLL: acute non lymphoblastic leukaemia $(n=40) .{ }^{c}$ Odds ratio (OR) were derived from an unconditional logistic model, adjusted for age, gender, hospitial, ethnic origin, maternal educational level, parental socio-professional categories, birth weight, length of pregnancy and number of previous pregnancies.

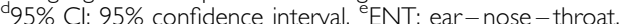

Table 5 Association between childhood acute leukaemia and infantile diseases, in children older than 2 years

\begin{tabular}{|c|c|c|c|c|c|c|c|c|c|c|c|c|}
\hline & \multicolumn{4}{|c|}{$\begin{array}{l}\text { All acute leukaemia } \\
\qquad n=\mathbf{2 4 7}\end{array}$} & \multicolumn{4}{|c|}{$\begin{array}{l}\text { Acute lymphoblastic leukaemia } \\
\qquad n=219\end{array}$} & \multicolumn{4}{|c|}{$\begin{array}{l}\text { Acute non-lymphoblastic leukaemia } \\
\qquad n=28\end{array}$} \\
\hline & $\mathrm{Ca}^{\mathrm{a}}(\%)$ & $\mathrm{Co}^{\mathrm{b}}(\%)$ & $O^{c}$ & $95 \% \mathrm{Cl}^{\mathrm{d}}$ & $\mathrm{Ca}(\%)$ & Co (\%) & OR & $95 \% \mathrm{Cl}$ & $\mathrm{Ca}(\%)$ & Co $(\%)$ & OR & $95 \% \mathrm{Cl}$ \\
\hline $\begin{array}{l}\text { Any infantile diseases } \\
\text { before } 2 \text { years }\end{array}$ & $37(15)$ & $36(15)$ & 0.9 & $(0.5-1.5)$ & $33(15)$ & $36(15)$ & 0.9 & $(0.5-1.5)$ & $4(16)$ & $36(15)$ & 1.1 & $(0.3-4.0)$ \\
\hline \multicolumn{13}{|c|}{ Number of infantile diseases } \\
\hline $\begin{array}{l}0 \\
1 \\
2+\end{array}$ & $\begin{array}{r}78(32) \\
125(50) \\
44(18)\end{array}$ & $\begin{array}{r}64(27) \\
142(60) \\
3 \mid(13)\end{array}$ & $\begin{array}{l}1.0 \\
0.9 \\
1.6\end{array}$ & $\begin{array}{r}\text { Reference } \\
(0.6-1.5) \\
(0.8-3.2)\end{array}$ & $\begin{array}{r}73(33) \\
11 \mid(50) \\
38(17)\end{array}$ & $\begin{array}{r}64(27) \\
\mid 42(60) \\
3 \mid(13)\end{array}$ & $\begin{array}{l}1.0 \\
0.9 \\
1.6\end{array}$ & $\begin{array}{r}\text { Reference } \\
(0.6-1.4) \\
(0.8-3.3)\end{array}$ & $\begin{array}{r}5(20) \\
14(56) \\
6(24)\end{array}$ & $\begin{array}{r}64(27) \\
142(60) \\
3 \mid(13)\end{array}$ & $\begin{array}{l}1.0 \\
1.2 \\
1.4\end{array}$ & $\begin{array}{r}\text { Reference } \\
(0.3-4.3) \\
(0.3-7.0)\end{array}$ \\
\hline
\end{tabular}

${ }^{\mathrm{a} C a:}$ Cases. ${ }^{\mathrm{b}} \mathrm{Co}$ : controls ( $\left.n=237\right) .{ }^{\mathrm{c}}$ Odds ratio (OR) were derived from an unconditional logistic model, adjusted for age, gender, hospital, ethnic origin, maternal educational level and parental socio-professional categories. ${ }^{9} 95 \% \mathrm{Cl}$ : $95 \%$ confidence interval.

mothers of two cases and two controls, who refused to participate. Controls were included from many diagnostic categories, none of those categories being related to the variables of interest. Our results were unchanged when the control group was restricted to each main diagnostic category. The cases and controls were very similar with respect to socio-demographic characteristics, i.e. maternal occupation at time of interview, maternal educational level, socio-professional categories and the rural/urban residential status.

Several previous studies on incident cases (Van Steensel-Moll et al, 1986; Petridou et al, 1997; Bener et al, 2001), and, in particular, several mortality studies (Stewart et al, 1958; MacMahon and Newill, 1962; Stark and Mantel, 1966) found that being the firstborn increased the risk of, or mortality related to, childhood AL. We did not find such an association, in line with many other studies based on incident cases (Shaw et al, 1984; McKinney et al, 1987; Kaye et al, 1991; Savitz and Ananth, 1994; Cnattingius et al, 1995; Roman et al, 1996; Shu et al, 1999; Infante-Rivard et al, 2000; Neglia et al, 2000; Rosenbaum et al, 2000). An OR less than unity, but far from significance, was observed with respect to a time interval to birth of the immediately elder sibling of less than 2 years, as was reported by Kaye et al (1991), but not by Neglia et al (2000).
A statistically-significant inverse association was observed between day-care attendance and childhood AL, as has previously been reported by Petridou et al (1993) and Infante-Rivard et al (2000). That association was not observed in three other studies (Petridou et al, 1997; Neglia et al, 2000; Rosenbaum et al, 2000). It is noteworthy that, in Neglia's study (Neglia et al, 2000), children attended day-care more often than in our study $(49 \%$ vs $27 \%)$, but started less often before age 1 than in our study $(15 \%$ vs $21 \%$ ). The statistically-significant interaction between day-care attendance and early common infections observed in our study suggests that infection in children attending day-care could differ in terms of frequency and/or type to those in other children. Diarrohea, upper respiratory tract infections and otitis have been shown to be more frequent in children attending day-care, compared to children not attending day-care (Haskins and Kotch, 1986; Wald et al, 1991; Reves et al, 1993). The statistically-significant inverse association between childhood AL and surgical procedures for ENT infection before age 2 is consistent with the results of a large study on ALL reported by Neglia et al (2000) in which the OR decreased as the number of episodes of otitis reported during the first year of life increases.

In our study, the surgical procedures for ENT infections before age 2 and day-care attendance among controls were 
significantly more frequent for urban residents than for rural residents. However, the cases and controls were similar with respect to urban/rural residential status, and our results remained unchanged when the analyses were restricted to urban children only.

Differential misclassifications such as under-declaration by the cases' mothers and/or over-declaration by the controls' mothers would seem minimal in the present study, due to the fact that the same standardised conditions were used to interview both the cases and the controls. Moreover, we obtained consistent results with respect to the mothers' declarations of their child's common infections before age 2 and the history of ENT surgery before age 2 . The latter constitutes a less sensitive but more specific and more readily remembered surrogate of early infections. Similar results regarding the risk of childhood $\mathrm{AL}$ and early infections have already been reported in other studies. A negative association with infections during the first year of life was observed by Van Steensel-Moll et al (1986). McKinney et al (1999) observed a negative association with neonatal infections. Our results are also consistent with those of Neglia et al (2000). In contrast, two studies found no association with early infection (McKinney et al, 1987; Dockerty et al, 1999).

Breast-feeding for at least 6 months was statistically-significantly and negatively associated with childhood AL. That finding has also been reported in several recent case-control studies (Schüz et al, 1999; Shu et al, 1999; Smulevich et al, 1999; Infante-Rivard et al, 2000; Bener et al, 2001). Two studies found a reduced risk of childhood leukaemia, although the reductions were not significant (Davis et al, 1988; Dockerty et al, 1999). Other studies did not, however, evidence any association (Van Steensel-Moll et al, 1986; Magnani et al, 1988; McKinney et al, 1987; Golding et al, 1990; Shu et al, 1995; Petridou et al, 1997; Rosenbaum et al, 2000; Hardell and Dreifaldt, 2001). Except for two studies, one conducted in Shanghai (Shu et al, 1995) and the other in Sweden (Hardell and Dreifaldt, 2001), the duration of breast-feeding was not considered (Van Steensel-Moll et al, 1986; McKinney et al, 1987; Magnani et

\section{REFERENCES}

Bener A, Denic S, Galadari S (2001) Longer breast-feeding and protection against childhood leukaemia and lymphomas. Eur J Cancer 37: 234-238

Breslow NE, Day NE (1980) Statistical Methods in Cancer Research, Vol. I. In The Analysis of Case-control studies Lyon: IARC Scientific Publications $\mathrm{N}^{\circ}$ 32. IARC

Cnattingius S, Zack MM, Ekbom A, Gunnarskog J, Kreuger A, Linet M, Adami HO (1995) Prenatal and Neonatal Risk Factors for Childhood Lymphatic Leukaemia. J Natl Cancer Inst 87: 908-914

Davis MK, Savitz DA, Graubard BI (1988) Infant feeding and childhood cancer. Lancet 2: 365-368

Dockerty JD, Skegg DCG, Herbison GP, Becroft DMO, Lewis ME (1999) Infections, vaccinations, and the risk of childhood leukemia. $\mathrm{Br} J$ Cancer 80: $1483-1489$

Doll R (1989) The epidemiology of childhood leukaemia. J R Statist Soc 152. $1-11$

Essex ME (1982) Feline leukemia: a naturally occuring cancer of infectious origin. Epidemiol Rev 4: 189-203

Golding J, Paterson M, Kinlen LJ (1990) Factors associated with childhood cancer in a national cohort study. Br J Cancer 62: 304-308

Greaves MF (1988) Speculations on the cause of childhood acute lymphoblastic leukemia. Leukemia 2: $120-128$

Greaves MF, Alexander FE (1993) An infectious etiology for common acute lymphoblastic leukemia in childhood? Leukemia 7: 349-360

Greaves MF (1997) Aetiology of acute leukaemia. Lancet 349: $344-349$

Hardell L, Dreifaldt AC (2001) Breast-feeding duration and the risk of malignant diseases in childhood in Sweden. Eur J Clin Nutr 55: 179-185

Haskins R, Kotch J (1986) Day care and illness: evidence, cost, and public policy. Pediatrics 77: 951-982

Infante-Rivard C, Fortier I, Olson E (2000) Markers of infection, breast-feeding and childhood acute lymphoblastic leukaemia. Br J Cancer 83: $1559-$ 1564 al, 1988; Golding et al, 1990; Petridou et al, 1997; Rosenbaum et al, 2000).

The usual infantile diseases - chickenpox, rubella and measles - were not associated with childhood AL. That finding is consistent with the results of recent studies (Dockerty et al, 1999; Schüz et al, 1999). McKinney et al (1987) observed an elevated OR $(\mathrm{OR}=4.1(1.5-11.3))$ between viral diseases comprising chickenpox, rubella, measles, mumps, viral meningitis, viral influenza and the risk of childhood leukaemia and lymphoma. In our study, an elevated and significant OR was also found for mumps $(\mathrm{OR}=3.2(1.1-9.0))$.

In conclusion, the main findings of the present study were the inverse relationships between childhood AL and early common infections, day-care and prolonged breast-feeding. These results are consistent with other publications and support Greaves' hypothesis, even though they are not specific to ALL.

\section{ACKNOWLEDGEMENTS}

We are grateful to Drs Diane Farkas, Kamila Kebaili, Anne Lambilliotte, Dominique Steschenko, Martine Zagouri, and Naïma Belkacem, who conducted the interviews, and to Martine Valdes, Isabelle Jaussent, Laurence Mandereau, and Dominique Ridondelli for technical assistance. We also thank the heads of the departments who helped us to include their patients as controls: Professors Bensahel, Bérard, Carlioz, Deberigny, Felipe, Herbault, Lascombes, Pouliquen, and Rigault. We are grateful to Andrew Mullarky for his skilful revision of the manuscript. This work was supported by grants from Inserm, the French Ministère de l'Environnement et de l'Aménagement du Territoire, the Association pour la Recherche contre le Cancer, the Fondation de France, the Fondation Jeanne Liot, the Fondation Weisbrem-Benenson, the Ligue Contre le Cancer du Val de Marne and the Ligue Nationale Contre le Cancer.
Kaye SA, Robison LL, Smithson WA, Gunderson P, King FL, Neglia JP (1991) Maternal reproductive history and birth characteristics in childhood lymphoblastic leukaemia. Cancer 68: $1351-1355$

Kinlen LJ (1988) Evidence for an infective cause of childhood leukaemia: comparison of a Scottish new town with nuclear reprocessing sites in Britain. Lancet ii: $1323-1326$

Kinlen LJ, Clarke K, Hudson C (1990) Evidence from population mixing in British new towns 1946-85 of an infective basis for childhood leukaemia. Lancet 336: $577-582$

Kinlen LJ (1995) Epidemiological evidence for an infective basis in childhood leukemia. Br J Cancer 71: 1 - 5

Kinlen LJ, Petridou E (1995) Childhood leukemia and rural population movements: Greece, Italy, and other countries. Cancer Causes Control 6 : $445-450$

MacMahon B, Newill VA (1962) Birth characteristics of children dying of malignant neoplasms. J Natl Cancer Inst 28: 231-244

Magnani C, Pastore G, Terracini B (1988) Infant feeding and childhood cancer. Lancet 2: 1136

McKinney PA, Cartwright RA, Saiu JMT, Mann JR, Stiller CA, Draper GJ Hartley AL, Hopton PA, Birch JM, Waterhouse JAH, Johnston HE (1987) The inter-regional epidemiological study of childhood cancer (IRESCC): a case-control study of aetiological factors for leukaemia and lymphoma. Arch Dis Child 62: 279-287

McKinney PA, Juszczak E, Findlay E, Smith K, Thomson CS (1999) Pre- and perinatal risk factors for childhood leukaemia and other malignancies: a Scottish case control study. Br J Cancer 80: $1844-1851$

Neglia JP, Linet MS, Shu XO, Severson RK, Potter JD, Mertens AC, Wen W, Robison LL (2000) Patterns of infection and day care utilization and risk of childhood acute lymphoblastic leukaemia. Br J Cancer 82: 234-240 
Petridou E, Kassimos D, Kalmanti M, Kosmidis H, Haidas S, Flytzani V, Tong D, Trichopoulos D (1993) Age of exposure to infections and risk of childhood leukaemia. Br Med J 307: 774

Petridou E, Trichopoulos D, Kalapothaki V, Pourtsidis A, Kogevinas M, Kalmanti M, Koliouskas D, Kosmidis H, Panagiotou JP, Piperopoulou F, Tzortzatou F (1997) The risk profile of childhood leukaemia in Greece: a nationwide case-control study. Br J Cancer 76: 1241 - 1247

Reves RR, Morrow AL, Bartlett IIIAV, Caruso CJ, Plumb RL, Lu BT, Pickering LK (1993) Child Day Care Increases the Risk of Clinic Visits for Acute Diarrhea and Diarrhea Due to Rotavirus. Am J Epidemiol 137: 97-107

Roman E, Ansell P, Bull D (1996) Leukaemia and non-Hodgkin's lymphoma in children and young adults: are prenatal and neonatal factors important determinants of disease? $\mathrm{Br} J$ Cancer 76: 406-415

Rosenbaum PF, Buck GM, Brecher ML (2000) Early Child-care and Preschool Experiences and the Risk of Childhood Acute Lymphoblastic Leukaemia. Am J Epidemiol 152: 1136 - 1144

Ross JA, Davies SM, Potter JD, Robison LL (1994) Epidemiology of childhood leukaemia, with a focus on infants. Epidemiol Rev 16: 243-272

Rothman KJ, Greenland S (1998) Modern Epidemiology, 2nd edn, USA: Lippincott, Williams and Wilkins Publishers

Savitz DA, Ananth CV (1994) Birth characteristics of childhood cancer cases, controls, and their siblings. Pediatr Hematol Oncol 11: 587-599

Schüz J, Kaletsch U, Meinert R, Kaatsch P, Michaelis J (1999) Association of childhood leukaemia with factors related to the immune system. $\mathrm{Br} J$ Cancer 80: $585-590$
Shaw G, Lavey R, Jackson R, Austin D (1984) Association of childhood leukaemia with maternal age, birh weight, and paternal occupation: a case-control study. Am J Epidemiol 119: 788-795

Shu XO, Clemens J, Zheng W, Ying DM, Ji BT, Jin F (1995) Infant Breastfeeding and the Risk of Childhood Lymphoma and Leukaemia. Int $J$ Epidemiol 24: 27-32

Shu XO, Linet MS, Steinbuch M, Wen WQ, Buckley JD, Neglia JP, Potter JD, Reaman GH, Robison LL (1999) Breast-feeding and risk of childhood acute leukaemia. J Natl Cancer Inst 91: 1765-1772

Smulevich VB, Silionova LG, Belyakova SV (1999) Parental occupation and others factors and cancer risk in children. Study methodology and nonoccupational factors. Int J Cancer 83: 712-717

Stark CR, Mantel N (1966) Effects of maternal age and birth order on the risk of mongolism and leukaemia. J Natl Cancer Inst 37: 687-698

Stewart A, Webb J, Hewitt D (1958) A survey of childhood malignancies. $\mathrm{Br}$ Med J 1495-1508

Van Steensel-Moll HA, Valkenburg HA, Van Zanen GE (1986) Childhood leukaemia and infectious diseases in the first year of life: a register-based case control study. Am J Epidemiol 124: 590-594

Wald ER, Guerra N, Byers C (1991) Upper respiratory tract infections in young children: duration of and frequency complications. Pediatrics 87: $129-133$ 